\title{
OCCURENCE OF OLIGOCHAETA LIVING ON LARVAE OF ODONATA FROM IPEÚNA (SÃO PAULO STATE, BRAZIL)
}

\author{
Juliano José Corbi ${ }^{1}$, Mário A. Jancso ${ }^{1,3}$, Susana Trivinho-Strixino ${ }^{1}$ and Evelise N. Fragoso ${ }^{2}$
}

Biota Neotropica v4 (n2) http://www.biotaneotropica.org.br/v4n2/pt/abstract?short-communication+BN03304022004

\author{
Date Received 07/02/2004 \\ Revised 08/23/2004 \\ Accepted 09/08/2004
}
${ }^{1}$ Laboratório de Entomologia Aquática, Departamento de Hidrobiologia, Universidade Federal de São Carlos, C. Postal 676, São Carlos, SP, Brasil. E-mail: pjcorbi@iris.ufscar.br
${ }^{2}$ Laboratório de Ictiologia e Dinâmica de Populações, Departamento de Hidrobiologia, Universidade Federal de São Carlos, C. Postal 676, São Carlos, SP, Brasil.
${ }^{3}$ Cientistas Associados Ltda., R. Alfredo Lopes, 1717, CEP: 13560-460, São Carlos, SP, Brasil.

\begin{abstract}
The occurrence of oligochaetes species living on larvae of Odonata is reported for the first time. There were found Nais variabilis (Piguet, 1906) (Oligochaeta: Naididae) and Chaetogaster diastrophus (Gruithuisen, 1828) (Oligochaeta: Naididae) living on Elasmothemis cannacrioides (Calvert, 1906) (Anisoptera: Libellulidae) and on Mnesarete (Cowley, 1934) (Zygoptera: Calopterygidae).
\end{abstract}

Key words: Oligochaeta, Odonata larvae, occurrence.

\section{Resumo}

A ocorrência de oligochaeta vivendo sobre Odonata é relatada pela primeira vez. Foram encontrados Nais variabilis (Piguet, 1906) (Oligochaeta: Naididae) e Chaetogaster diastrophus (Gruithuisen, 1828) (Oligochaeta: Naididae) vivendo sobre Elasmothemis cannacrioides (Calvert, 1906) (Anisoptera: Libellulidae) e sobre Mnesarete (Cowley, 1934) (Zygoptera: Calopterygidae).

Palavras-chave: Oligochaeta, larvas de Odonata, ocorrência.

http://www.biotaneotropica.org.br 


\section{Introduction}

Species of oligochaetes inhabiting on other freshwater animals have been cited by Marcus 1941, Brinkhurst \& Jamieson 1980, Kahl \& Konopacka 1981, Righi 1984, Anderson \& Holm 1987, Fernandez et al. 1991, Brinkhurst \& Marchese 1991, Corbi et al. (2005). However, there are few published studies concerning Brazilian species (Righi 1984). Here, we report for the first time the presence of oligochaetes species inhabiting on Odonata larvae.

\section{Material and Methods}

The organisms were collected manually, using a manual network $1,50 \mathrm{~m} \times 1,0 \mathrm{~m}(0.5 \mathrm{~mm}$ of mesh), in the Lapa and Cantagalo streams. These aquatic systems are located in the town of Ipeúna (São Paulo, Brazil) within the hydrographic basin of the Piracicaba-Capivari-Jundiaí $\left(22^{\circ} 22^{\prime} \mathrm{S}\right.$ and $47^{\circ} 46^{\prime} \mathrm{W}$ ). The Lapa stream is characterized by the presence of forested and pasture areas in its surroundings. The water has high values of dissolved oxygen $(8,7 \mathrm{mg} / \mathrm{L})$, low electric conductivity $(40 \mathrm{mS} / \mathrm{cm})$ and slightly acid $\mathrm{pH}$ values $(6,0)$. The Cantagalo stream is characterized by deforestation margin with pasture areas. Dissolved oxygen values are high $(8,7 \mathrm{mg} / 1)$, electric conductivity is low $(40 \mathrm{mS} / \mathrm{cm})$ and the $\mathrm{pH}$ is less acid $(6,4)$.

The aquatic worms were sorted under stereoscopic microscope and optic microscopy, processed and identified following Brinkhurst \& Jamieson (1980), Righi (1984) and Brinkhurst \& Marchese (1991) techniques. The Odonata identification was Patricia Santos Ferreira Peruquetti's courtesy. The specimens have been duly deposited in the collection of the Aquatic Entomology Laboratory of the Federal University of São Carlos, SP, Brazil.

\section{Results and Discussion}

We recorded two species of aquatic oligochaetes of the Naididae family: Nais variabilis (Piguet, 1906) and Chaetogaster diastrophus (Gruithuisen, 1828). These species are living on larvae of the Odonata Elasmothemis cannacrioides (Calvert, 1906) and Mnesarete (Cowley, 1934) (Fig. 1). Among the 320 Odonata collected, we observed that 6 percent were inhabited by the oligochaetes species living mainly below and above the wing cases and on the superior part of the Odonata abdomen. Along with the Oligochaetes species we found 25 worms, among which $\mathrm{N}$. variabilis was the most abundant species followed by $\mathrm{Ch}$. diastrophus.

Other authors have also found Naididae inhabiting aquatic animals, specially belonging at the genus Chaetogaster and Nais. More detailed information on this subject will be published elsewhere (Corbi et al. 2005).
The oligochaetes probably are neither particularly characteristic of nor strongly connected with their hosts, as has been pointed out for sponges by Kahl \&Konopacka (1981). Therefore, more information is required on this theme, especially considering that the symbiosis in freshwater may involve evolutionary advantages, such as better feeding opportunities, increased mobility, protection from disturbances and reduced risk of predation (Tokesshi 1999).

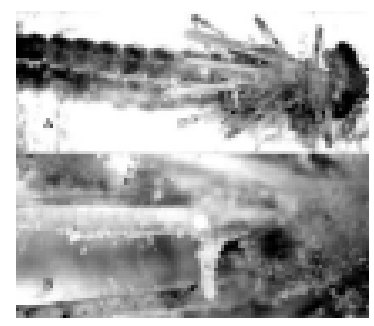

Figure 1. A. Chaetogaster diastrophus on the dorsal side of Mnesarete. B. Zoom in Chaetogaster diastrophus.

\section{Acknowledgements}

We would like to thank Fábio de Oliveira Roque for the fruitful suggestions. We also like to thank Dr. P. Melnikov for paper revision in its English form. Financial support: CAPES.

\section{References}

ANDERSON, R.V. \& HOLM, D.J. 1987. Chaetogasterlimnaei (Oligochaeta, Naididae) infesting unionid mollusks (Pelecypoda, Unionidae) and Corbicula-fluminea (Pelecypoda, Corbiculidae) in pool-19, Mississippi river. J. Freshwater Ecol., 4:61-64.

BRINKHURST, R.O. \& JAMIESON, B.G.M. 1980. Aquatic Oligochaeta of the World. University of Toronto Press.

BRINKHURST, R.O. \& MARCHESE, M.R. 1991. Guia para la identificación de oligoquetos acuáticos continentales de Sud y Centroamerica. Associación Ciencias Naturales del Litoral. J. Maciá, 1933. Santo Tome (3016) - Argentina.

CORBI, J.J., ROQUE, F.O., TRIVINHO-STRIXINO, S. \& ALVES, R.G. 2005. Records of Oligochaetes in Freshwater Sponges, on Bryozoans and on Colonial Hydrozoans from Brazil. Braz. Journal of Biol., Vol 65. (In press).

FERNANDEZ J., GOATER, T.M. \& ESCH, G.W. 1991. Population-dynamics of Chaetogaster-limnaei-limnaei (Oligochaeta) as affected by a trematode parasite in Helisoma-anceps (Gastropoda). Am. Midl. Nat., 125:195205. 
KAHL, K. \& A. KONOPACKA. 1981. Oligochaeta inhabiting the colonies of the sponge Spongilla lacustris (L.) in the River Gac. Acta Hydrobiol., 23:243-249.

MARCUS, E. 1941. Sobre Bryozoa do Brasil. Bolm Fac. Fil. Ci. Letras. Univ. São Paulo, Zoologia, 5:3-208.

RIGHI, G. 1984. Manual de identificação de invertebrados Límnicos do Brasil. Brasília, CNPq.

TOKESHI, M. 1999. On evolution of commensalism in the Chironomidae. Freshwater Biol., 29:481-489.

Title: Occurence of Oligochaeta living on larvae of Odonata from Ipeúna (São Paulo State, Brazil)

Authors: Juliano José Corbi, Mário A. Jancso, Susana Trivinho-Strixino and Evelise N. Fragoso

Biota Neotropica, Vol. 4 ( number 2): 2004

http://www.biotaneotropica.org.br/v4n2/pt/ abstract?short-communication+BN03304022004

Date Received 07/02/2004

Revised 08/23/2004

Accepted 09/08/2004

ISSN 1676-0611 